\title{
THE MATHEMATICAL MODEL OF ELECTROENCEPHALOGRAPHIC AND ELECTROMYOGRAPHIC SIGNALS FOR THE TASK OF HUMAN COMMUNICATIVE FUNCTION RESTORATION
}

\author{
Oksana Dozorska
}

\author{
Ternopil Ivan Puluj National Technical University, Ternopil, Ukraine
}

\begin{abstract}
Summary. The article is devoted to the questions of substantiation the mathematical model of the electroencephalographic signal, registered from the surface of head near the speech centers of brain, and the electromyographic signal, registered from the neck surface near the vocal folds, for the problem of indirect restoration the human communicative function. The possibility of representing these signals in the form of a stationary random process is analyzed and it is established that such a model is not adequate to the research problem, in particular, to identify the time moments of emergence the signs of the communicative function implementation. The mathematical model of electroencephalographic and electromyographic signals in the form of a piecewise stationary random process, that is adequate to their physical nature and research tasks, is substantiated.

Key words: communicative function, electroencephalographic signal, electromyographic signal, mathematical model, piecewise stationary random process.
\end{abstract}

Statement of the problem. Taking into account the significant increase in the number of people with limited or lost communicative function, which is the most important means of communication, the development of the ways to compensate or restore this function is important in the field of rehabilitation medicine. Particularly important is the development of the ways of indirect restoration this function, as this will provide the opportunity for communication for people with irreversible body disorders that directly implement the communicative function. The essence of the method of indirect human communicative function restoration by means of synchronous selection and subsequent processing of biosignals that arise in the process of realization of this function is described in papers [ $1-3]$. Particularly, it is offered [1 -3$]$ to perform synchronous selection and processing of electroencephalographic (EEG) signals registered from the patient's head near the linguistic centers of the brain and electromyographic (EMG) signals registered from the patient's neck surface near the vocal folds. At the same time, the methods of such biosignals processing will determine the algorithms of software functioning for indirect human communicative function restoration. In order to develop EEG and EMG signals processing methods, it is necessary to justify the choice of their mathematical model, which should be adequate to the research problem and the physical nature of these signals. The mathematical model should contain informative features that could identify the signs of the communicative function implementation process in the structure of the EEG and EMG signals.

Analysis of available investigations. In the structure of EEG signals, changes in the electrical activity of the brain are reflected, caused by the need to provide mechanisms for selfregulation and functioning of all organs and systems of the human body, to implement the function of adaptation to the variables of external and internal factors that affect the human 
body, etc. [4]. Accordingly, in the structure of EEG signals, electrical responses to the processes that provide the communicative language function will also be displayed. In this case, the EEG signal represents the superposition of the potentials of the action of all neurons with varying degrees of influence on the resulting EEG signal [4, 5]. While carrying out the electroencephalographic investigations, the vast majority of processing methods are based on the mathematical model of EEG signals in the form of the stationary random process $[4-6]$. Also, in some cases, the EEG signal is considered as a set of sites that can be conventionally considered as stationary or, quasi-stationary, and whose length is large enough to produce statistically valid results [4].

In electromyographic investigations, involving the evaluation of the functional state of muscles and endings of peripheral nerves, EMG signal is also considered as a stationary random process $[7,8]$.

The model in the form of the stationary random process implies the immutability of the probabilistic characteristics of EEG and EMG signals in time. However, in the structure of these signals, signs of the communicative function implementation must be manifested, which, in turn, will change their probabilistic characteristics, and the detection of the time moments of the appearance of these signs forms the basis of the method of mediated restoration of the communicative function described in papers [1 - 3].

The objective of thepaper is to substantiate the choice of the mathematical model of synchronously registered EEG and EMG signals, which would take into account in its structure the signs of the communicative function implementation, and the methods developed on the basis of such a model, the processing of these biosignals would enable the identification of individual components of the speech process (phonemes, words ) to ensure the possibility of exchanging information among people with body disorders that directly implement the communicative function.

The results of the investigation. While implementing the communicative function, the exchange of information between people (communication) is carried out by forming voice signals, which structure contains the necessary information for transmission. Elementary constituents of the voice signal transmitting verbal information are phonemes (sounds of the language), which are combined into words and phrases. In this case, in the process of forming voice signals in the stream of exhaled air, the signal source (the lungs, vocal folds) generates a sound signal with characteristic repeatability - the main tone (MT) generated by vocal folds, which are excited by a quasiperiodic sequence of nerve impulses. The speech apparatus (tongue, lips, oral cavity, nasal cavity) forms the phonetic structure of the signal. Nerve impulses which, in the process of words or phrases pronunciation, control the work of the vocal apparatus, are formed in the speech centers of the brain.

Accordingly, the problem of communicative function restoration is reduced to the task of detecting and identifying signs of individual phonemes in the structure of EEG and EMG signals.

The last problem is close to the task of speech recognition - the detection of signs of individual phonemes in the structure of voice signals and their subsequent identification $[9,10]$. In acoustics, the recognition of individual phonemes in the structure of voice signals is carried out in response to changes in the shape of the by-pass signal component (Fig. 1, b) and in terms of the main tone frequency (MTF) in the case of recognition of vowels and consonant vocalized sounds. MTF is reversed to the MT period (Fig. 1, c), and its value coincides with the frequency of placing the first maximum of the estimates of the amplitude spectrum of the voice signal (Fig. 1.g). 


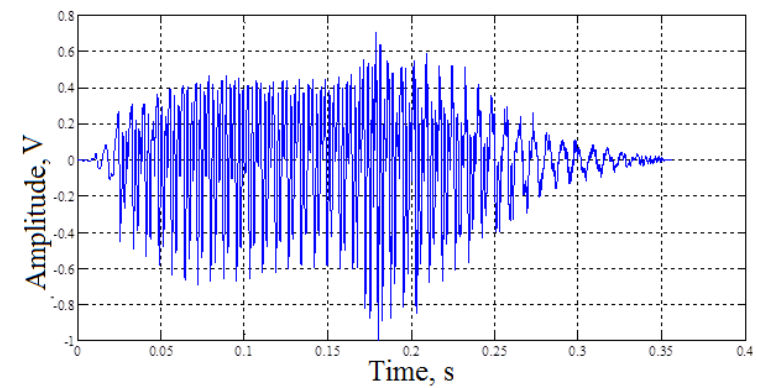

a)

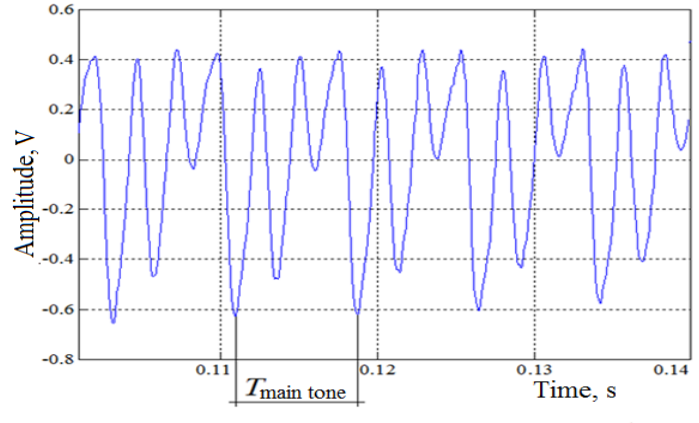

c)

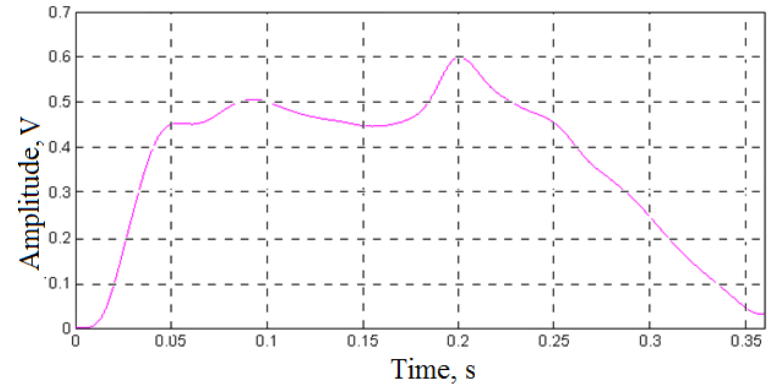

b)

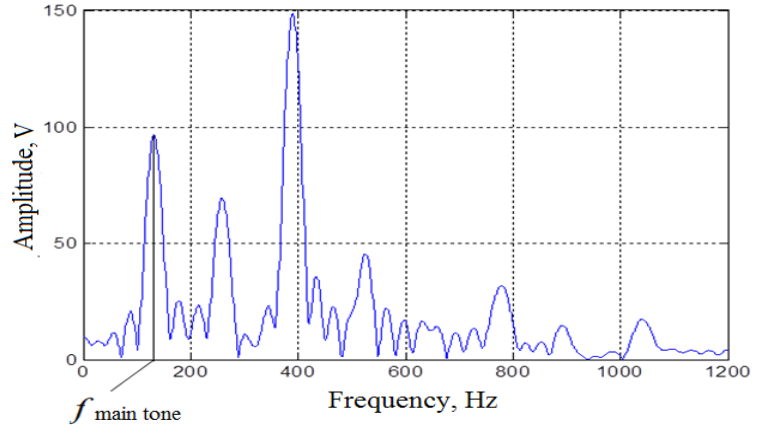

d)

Figure 1. The look of the voice signal (a), the enveloping signal (b), the sampling from the carrier component of the signal (c) and the evaluation of the amplitude spectrum of the signal (e)

According to the above mentioned, there shoul be the signs of the communicative function implementation in the structure of EEG and EMG signals such as: in the structure of EEG signals - signs of the beginning and end of the speech process; in the structure of EMG signals - signs of MT, by which one can identify vowels as well as consonant vocalized phonemes. To substantiate the choice of the mathematical model of these signals, the following assumptions were made: 1) EEG and EMG areas in the state of rest - in the absence of the broadcasting process for unchanged additional factors (emotional state, position of the patient in space, eyes closed, external conditions) - will be stationary; areas of EEG and EMG signals during the implementation of the communicative function will be stationary, but different from the analogous sites for the rest of the parameters (estimation of mathematical expectation, dispersion, etc.). The task of revealing the manifestations in the structure of the EEG and EMG signals signs of the process the communicative function implementation is reduced to the problem of identifying the characteristic changes for these biosignals characteristic for such process.

Detection of changes in the properties of EEG and EMG signals is one of the common problems of the analysis and processing of biomedical information in the field of neurofunctional research. The jump-like changes in the properties of such signals occurring at unknown time points can be described as the disorder occurrence in the structure of these signals [11]. Classical methods for detecting disorder [11] make it possible to detect single disorder of the random process and obtain the estimate of the maximum probability of the jump coordinates. However, in the case of detecting changes in the structure of EEG signals that characterize the presence of the speech process signs or changes in the structure of EMG signals characterizing the presence of the main tone signs, it is necessary to identify the sequence of jumps. In this case, it is reasonable to use a piecewise stationary random process as a mathematical model of EEG and EMG signals. [12].

In case of the mathematical model application in the form of the piecewise stationary random process [12], EEG and EMG signals can be presented as follows: 


$$
\Xi_{n}(t)=\left(\xi_{1}(t), \xi_{2}(t), \ldots, \xi_{n}(t)\right)
$$

where: $\Xi_{n}(t)$ is the random vector-process, given on the interval $t \in[a, b]$; sequence of sets $B_{k}, k=\overline{1, n}$ is the interval $[a, b]$ distribution by points $t_{1}, t_{2}, \square, t_{k} ; I_{B_{k}}(t)$ is the indicator

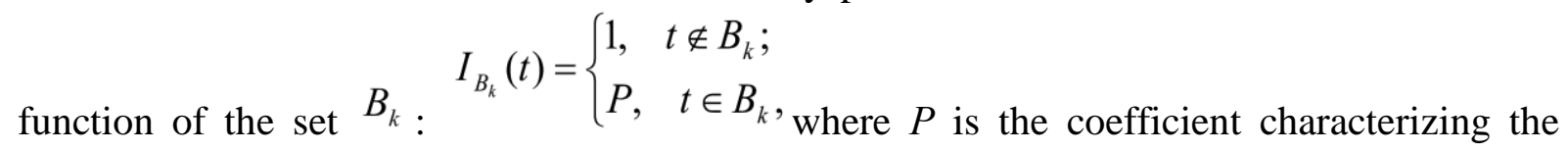
change in the process parameters. In this case, the random process in the form [12]:

$$
\xi_{\Sigma}(t)=\sum_{k=1}^{n} \xi_{k}(t) I_{B_{k}}(t)
$$

is called the disorder process, and moments $t_{1}, t_{2}, \ldots, t_{n}$ are disruption points [12].

According to this, the problem is reduced to the identification of the time moments of the change in the parameters of the stationary areas of EEG and EMG signals, and according to (1) - the time moments of the disorder occurence in the structure of these signals. At the same time, the estimation of the time moments of the beginning and end of the speech process as well as the characteristics of the MT will be interval estimates, therefore, justification of the choice of the value of the time interval of the evaluation will be necessary in order to minimize the error of the values of the required time points.

For processing, it is suggested to use the methods of spectral correlation analysis of stationary random processes, and to process the signal at intervals of the specified duration ( $\mathrm{t} 1-\mathrm{t} 2, \mathrm{t} 2-\mathrm{t} 3, \ldots, \mathrm{tn}-1-\mathrm{tn})$. Theoretically it is shown in Fig. 2.

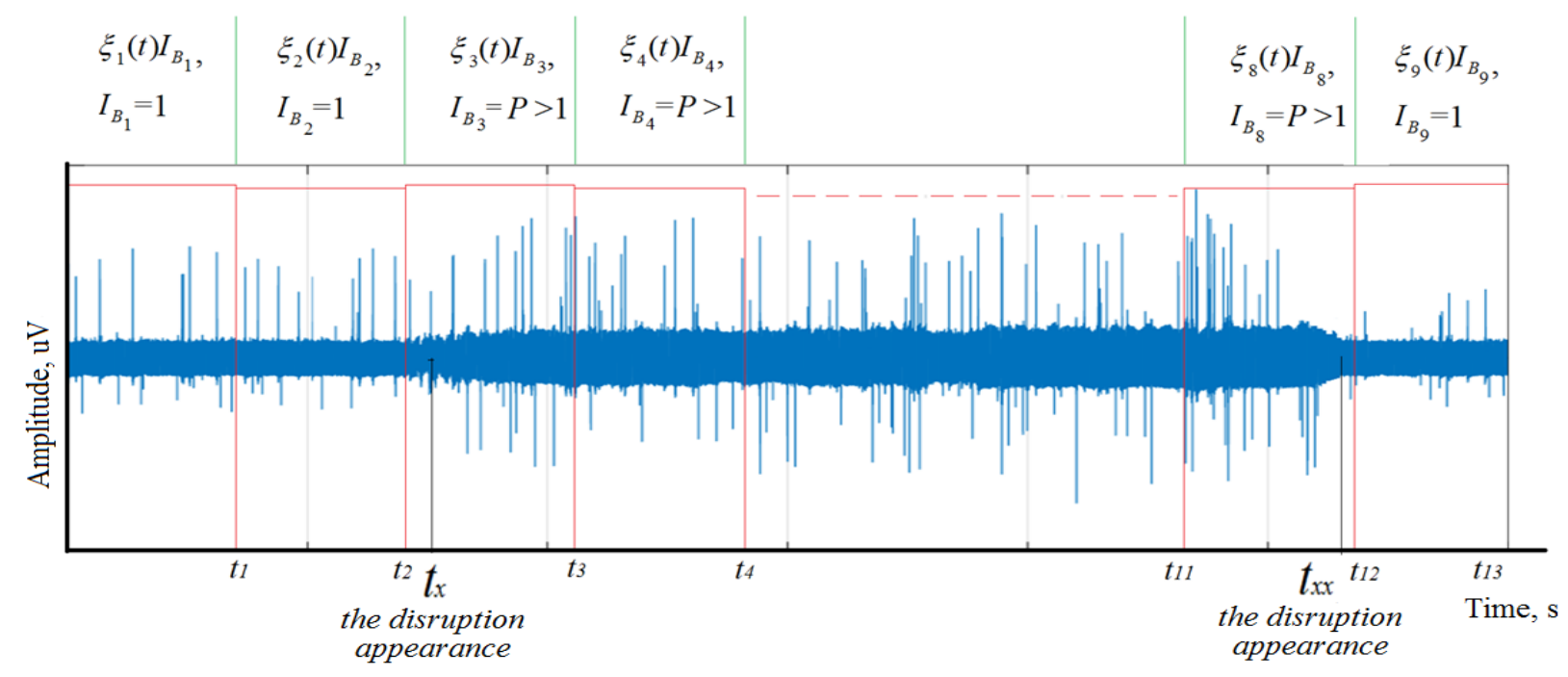

Figure 2. Detection of EEG signal disruption, which characterizes increase of brain activity

Verification of the mathematical model. To verify the proposed mathematical model, the EEG signals were selected using the 16-channel electroencephalograph Neyrok, KhAI Medica. Recording duration was 2 minutes. During the recording, the investigated person was offered during the first minute (approx.) to try to think about nothing, and during the second minute - intensively «mentally» repeat the word «up». In the structure of EEG signal (Fig. 3), 
this manifested itself in increasing the amplitude at the time $t_{x}$, which is defined as thqe time point of disorder occurrence - the beginning of the communicative function implementation.

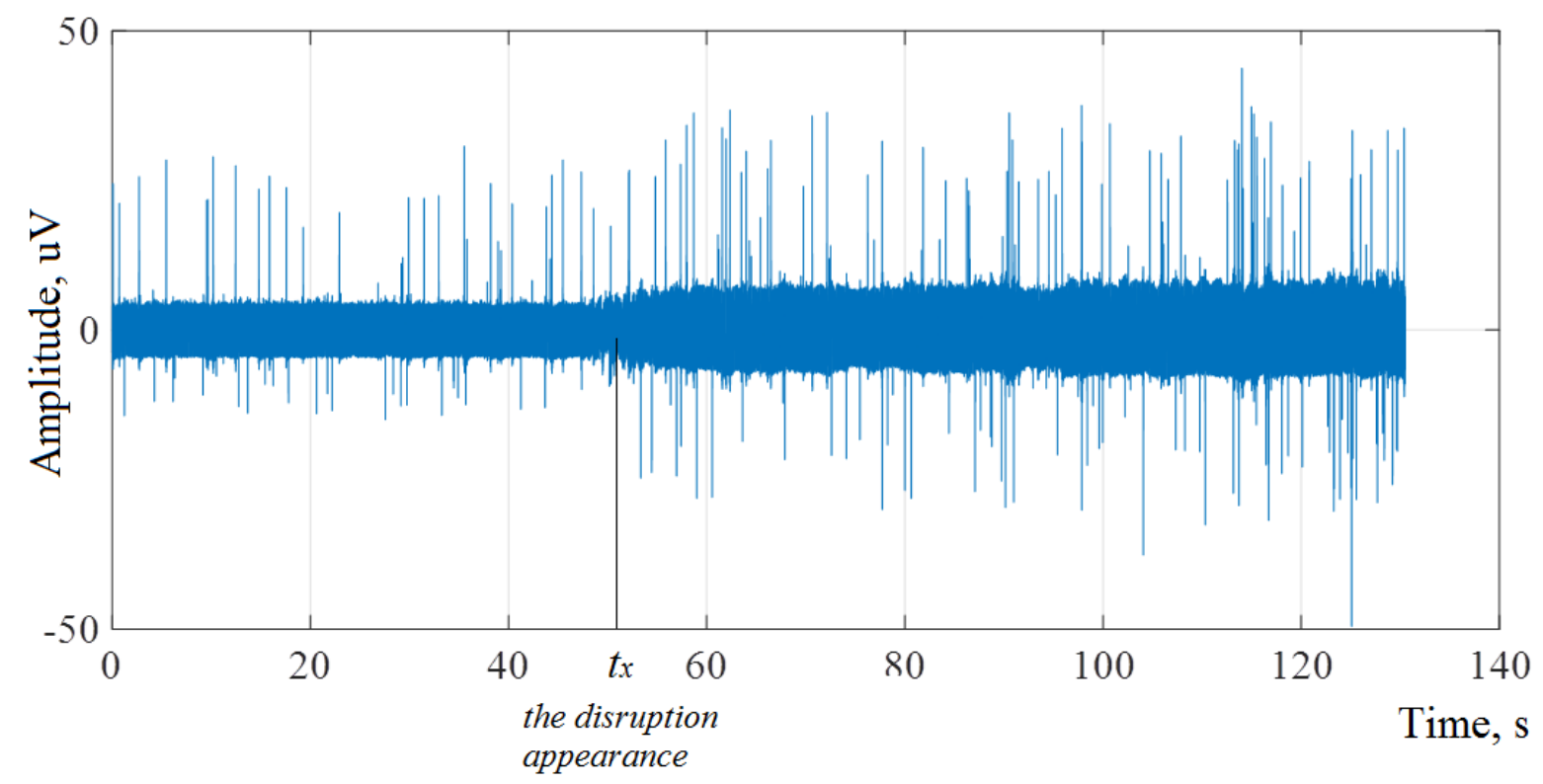

Figure 3. Registered EEG signal with a sign of the speech process start

As the criterion for determining the time moments of the beginning and end of the speech process, the variation of the averaged estimates of the spectral capacity density calculated within the limits of the sliding window, the parameters of which were selected in accordance with [3] was used. It is determined that the values of variation increase by more than one order in presence of brain activity signs.

Fig. 4 shows the appearance of the synchronously registered voice signal (consonant vocalized sound [1]) and EMG signal, in order to find signs of OT (which characterizes the voice signal) in the structure of the EMG signal. The existence of interconnection of the synchronously registered EMG signal and the voice signal and the presence of MT signs in the of the EMG signal structure was confirmed in paper [2].

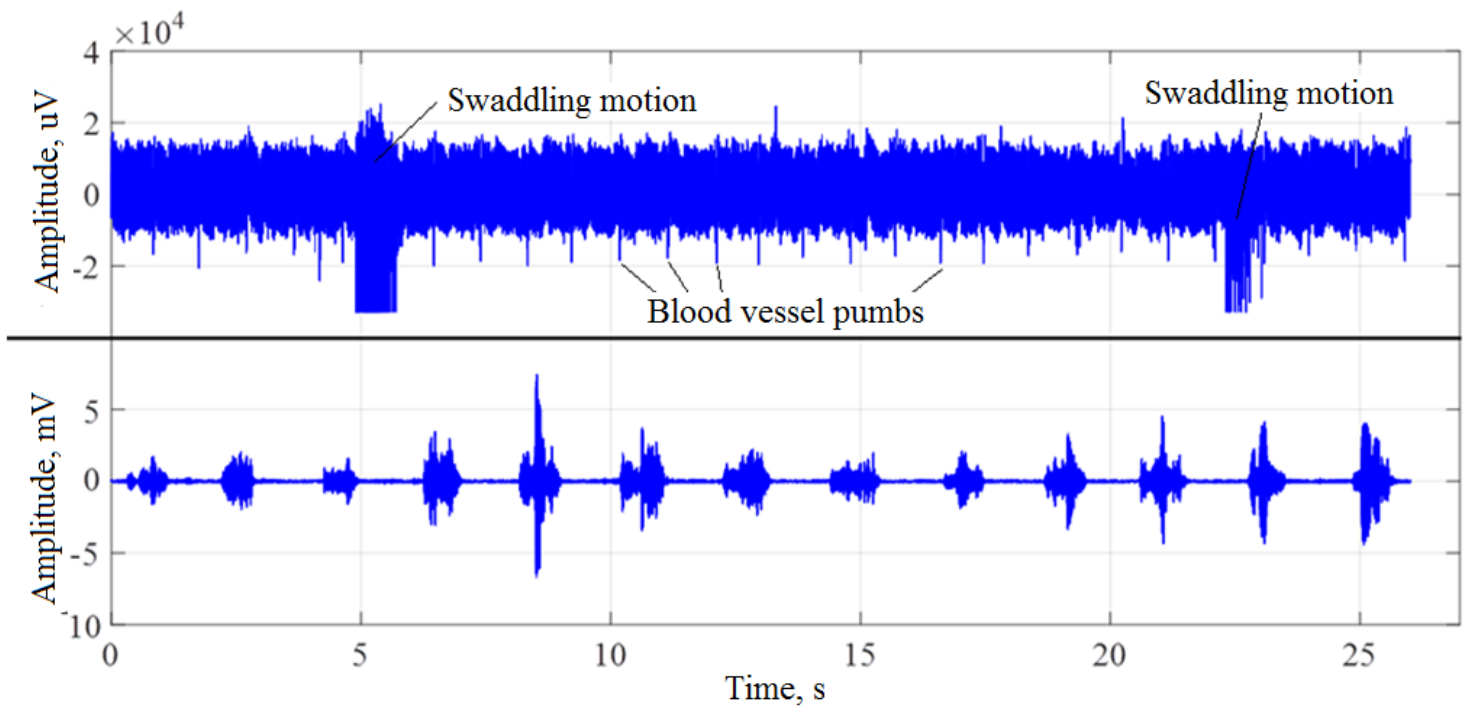

Figure 4. Registered EMG signal (upper figure) and voice signal $[l]$ (bottom figure), synchronously recorded 
Relatively the conclusion about the adequacy of the mathematical model of EEG and EMG signal in the form of the piecewise stationary random process of the investigated problem and the physical nature of this type of signals is made.

Conclusions The substantiation of the choice of the mathematical EEG and EMG signals model for the problem of indirect restoration of the human communicative function, which would be adequate to the physical nature of this kind of signals and the given task was made.

It is defined that the model in the form of the stationary random process has limited possibilities concerning detection of the time moments of changes in the structure of EEG and EMG signals, which are the result of the communicative function implementation, since such a model implies the immutability of the structure of these signals in time. The piecewise stationary random process is substantiated as the mathematical model of EEG and EMG signals.

The results of verification of the offered mathematical EEG and EMG signals model confirmed the adequacy of such model to the physical nature of these signals and the problem of indirect rerestoration of the communicative function.

\section{References}

1. Dozors'kyy V.H. Vidbir ta opratsyuvannya biosyhnaliv dlya zadachi vidnovlennya komunikatyvnoyi funktsiyi movy lyudyny / V.H. Dozors'kyy, O.F. Dozors'ka, Ye.B. Yavors'ka //Visnyk Kremenchuts'koho natsional'noho universytetu imeni Mykhayla Ostrohrads'koho. Kremenchuk: KrNU, 2017. Vypusk 4 (105). P. 9 - 14 .

2. Dozors'kyy V.H. Zastosuvannya neyrokhronaksychnoyi teoriyi fonatsiyi dlya zadachi vidnovlennya komunikatyvnoyi funktsiyi movy lyudyny / V.H. Dozors'kyy, O.F. Dozors'ka, L.Ye. Dediv, I.Yu. Dediv, Ye.B. Yavors'ka // Znanstvena misel. Slovenia, 2017. \#12. P. $57-61$.

3. Yavors'ka Ye. Metod opratsyuvannya biosyhnaliv dlya zadachi vidnovlennya komunikatyvnoyi funktsiyi lyudyny / Ye. Yavors'ka, V. Dozors'kyy, L. Dediv, O. Dozors'ka // «Vcheni zapysky Tavriys'koho natsional'noho universytetu imeni V.I. Vernads'koho. Seriya: Tekhnichni nauky» / K.: Tavriys'kyy natsional'nyy universytet imeni V.I. Vernads'koho, 2018. T. 29 (68), № 4. P. $26-30$.

4. Ot neyrona k mozgy / Per. s angl. P.M. Balabana, A.V. Galkina, R.A. Giniatullina, R.N. Khazipova, L.S. Khiruga. M.: Yeditorial URSS, 2003. 672 p.

5. Klinicheskaya elektroentsefalografiya (s elementami epileptologii). Rukovodstvo dlya vrachey / L.R. Zenkov. 3-ye izd. M.:MEDpressinform, 2004. 368 p.

6. G. Ramsberger, «The human brain: Understanding the physical bases of intrapersonal communication,» in Intrapersonal communciation: Different voices, different minds, D.R Vocate (Ed). (Pp. 57 - 76) Erlbaum 1994.

7. Kasatkina L.F. Elektromiograficheskiye metody issledovaniya $\mathrm{v}$ diagnostike nervno-myshechnykh zabolevaniy. Igol'chataya elektromiografiya / Kasatkina L.F., Gil'vanova O.V. M, 2010. 416 p.

8. Impact of Different Speaking Modes on EMG-based Speech Recognition / Michael Wand, Szu-Chen Stan Jou, Arthur R. Toth, Tanja Schultz // Interspeech 2009, 6 - 10 September, Brighton UK. Pp. 648 - 651.

9. Mikhaylov V.G. Iz istorii issledovaniy preobrazovaniya rechi / V.G. Mikhaylov // Rechevyye tekhnologii. 2008. № 1. P. $93-113$.

10. Agranovskiy A.V. Teoreticheskiye aspekty algoritmov obrabotki i klassifikatsii rechevykh sig̀nalov / A.V. Agranovskiy, D.A. Lednov. M.: Radio i svyaz', 2004. 164 p. ISBN 5-256-01743-8.

11.Zhiglyavskiy A.A., Kraskovskiy A.Ye. Obnaruzheniye razladki sluchaynykh protsesov v zadachakh radiotekhniki. L.: Izd-vo LGU, 1988. 224 p.

12. Metodi otsínyuvannya tochností ínformatsíyno-vimíryuval'nikh sistem díagnostiki: Monografíya / N.B. Marchenko, V.V. Nechiporuk, O.P. Nechiporuk, YU.V. Pepa. K.: NAU, 2014. 377 p.

\section{Список використаної літератури}

1. Дозорський, В.Г. Відбір та опрацювання біосигналів для задачі відновлення комунікативної функції мови людини [Текст] / В.Г. Дозорський, О.Ф. Дозорська, Є.Б. Яворська // Вісник Кременчуцького національного університету імені Михайла Остроградського. - Кременчук: КрНУ, 2017. - Випуск 4 (105). - C. 9 - 14.

2. Застосування нейрохронаксичної теорії фонації для задачі відновлення комунікативної функції мови людини / В.Г. Дозорський, О.Ф. Дозорська, Л.С. Дедів, І.Ю. Дедів, С.Б. Яворська // Znanstvena misel. - Slovenia, 2017. - № 12. - C. 57 - 61.

3. Метод опрацювання біосигналів для задачі відновлення комунікативної функції людини [Текст] / Є. Яворська, В. Дозорський, Л. Дедів, О. Дозорська // «Вчені записки Таврійського національного 
університету імені В.І. Вернадського. Серія: Технічні науки». - К.: Таврійський національний університет імені В.I. Вернадського, 2018. - Т. 29 (68), № 4. - С. 26 - 30.

4. От нейрона к мозгу [Текст]; пер. с англ. П.М. Балабана, А.В. Галкина, Р.А. Гиниатуллина, Р.Н. Хазипова, Л.С. Хируга. - М.: Едиториал УРСС, 2003. - 672 с.

5. Клиническая электроэнцефалография (с элементами эпилептологии). Руководство для врачей [Текст] / Л.Р. Зенков. - 3-е изд. - М.:МЕДпрессинформ, 2004. - 368 с.

6. G. Ramsberger, «The human brain: Understanding the physical bases of intrapersonal communication,» in Intrapersonal communciation: Different voices, different minds, D.R Vocate (Ed). (Pp. 57 - 76) Erlbaum 1994.

7. Касаткина, Л.Ф. Электромиографические методы исследования в диагностике нервно-мышечных заболеваний. Игольчатая электромиография [Текст] / Л.Ф. Касаткина, О.В. Гильванова. M., 2010. - $416 \mathrm{c}$.

8. Impact of Different Speaking Modes on EMG-based Speech Recognition / Michael Wand, Szu-Chen Stan Jou, Arthur R. Toth, Tanja Schultz // Interspeech 2009, 6 - 10 September, Brighton UK. - Pp. $648-651$.

9. Михайлов В.Г. Из истории исследований преобразования речи [Текст] / В.Г. Михайлов // Речевые технологии. - 2008. - № 1. - С. 93 - 113.

10. Аграновский, А.В. Теоретические аспекты алгоритмов обработки и классификации речевых сигналов [Текст] / А.В. Аграновский, Д.А. Леднов. - М.: Радио и связь, 2004. - 164 с. ISBN 5-256-01743-8.

11. Жиглявский, А.А., Обнаружение разладки случайных процесов в задачах радиотехники [Текст]/ А.А. Жиглявский, А.Е. Красковский. - Л.: Изд-во ЛГУ, 1988. - 224 с.

12. Методи оцінювання точності інформаційно-вимірювальних систем діагностики: монографія [Текст] / Н.Б. Марченко, В.В. Нечипорук, О.П. Нечипорук, Ю.В. Пепа. - К.: НАУ, 2014. - 377 с.

\title{
УДК 612.78:661.831-073.97-71:519.24
}

\section{МАТЕМАТИЧНА МОДЕЛЬ ЕЛЕКТРОЕНЦЕФАЛОГРАФІЧНОГО ТА ЕЛЕКТРОМІОГРАФІЧНОГО СИГНАЛІВ ДЛЯ ЗАДАЧІ ВІДНОВЛЕННЯ КОМУНІКАТИВНОЇ ФУНКЦІї ЛЮДИНИ}

\section{Оксана Дозорська}

\author{
Тернопільський наџіональний технічний університет імені Івана Пулюя, \\ Тернопіль, Україна
}

\begin{abstract}
Резюме. Проведено обгрунтування вибору математичної моделі ЕЕГ та ЕМГ сигналів для задачі опосередкованого відновлення комунікативної функиії людини. Обгрунтування вибору математичної моделі проводилось виходячи із того, щчо якісна модель повинна бути адекватною фізичній природі такого роду сигналів та поставленій задачі опосередкованого відновлення комунікативної функиії людини. Проаналізовано можливість подання ЕЕГ та ЕМГ сигналів у вигляді стаціонарного випадкового процесу та встановлено, щзо така модель відображає складність иих ситналів у спектральному розподілі потужності, але не має засобів оцінювання їхньої часової структури, шзо є необхідним для виявлення та ідентифікачії ознак окремих фонем, які є результатом реалізації комунікативної функції і на основі яких можна проводити компенсацію порушень або відновлення иієї функиії. Шляхом аналізу процесу формування голосових сигналів при реалізації комунікативної функиї показано, щзо в структурі ЕЕГ та ЕМГ сигналів мають проявлятись ознаки, за якими можна проводити виявлення та ідентифікацію окремих фонем. При изьому висунуто припущення, щцо ділянки ЕЕГ та ЕМГ сигналів у стані спокою (відсутність процесу мовлення) будуть стаціонарними, а ділянки таких сигналів, щео відповідають процесу мовлення, також будуть стаціонарними, але з відмінними від аналогічних ділянок для стану спокою параметрами. Відповідно, як математичну модель ЕЕГ та ЕМГ сигналів обгрунтовано кусково стаціонарний випадковий прочес. На основі обтрунтованої математичної моделі можна реалізувати методи опрацювання ЕЕГ та ЕМГ сигналів і реалізувати на їх основі технічні засоби опосередкованого відновлення комунікативної функиії людини.
\end{abstract}

Ключові слова: комунікативна функиія, електроенцефалографічний сигнал, електроміографічний сигнал, математична модель, кусково стаціонарний випадковий прочес. 